\title{
EFFECT OF GAMMA IRRADIATION TECHNIQUE ON THE MICROBIAL AND NUTRITIONAL QUALITY OF EDIBLE BAMBOO SHOOT (Dendrocalamus asper) FOR SHELF-LIFE ENHANCEMENT
}

\author{
Dushyant Singh ${ }^{1,2^{*}}$, Rudrangshu Chatterjee ${ }^{2}$, Abhishek Chauhan ${ }^{3 *}$, Madan Lal Aggarwal ${ }^{2}$, \\ Ajit Varma ${ }^{1}$, A.C. Kharkwal ${ }^{1 *}$

\footnotetext{
${ }^{1}$ Amity Institute of Microbial Technology, Amity University, Sector-125, Noida-201313, India

${ }^{2}$ Shriram Institute for Industrial Research, 19, University Road, Delhi-1 10007, India
} \\ ${ }^{3}$ Amity Institute of Environmental Toxicology, Safety and Management, Amity University, Sector-125, Noida-201313, India
}

Received - May 29, 2021; Revision - July 17, 2021; Accepted - August 10, 2021

Available Online -August 30, 2021

DOI: http://dx.doi.org/10.18006/2021.9(4).517.527

KEYWORDS
Bamboo shoot
Dendrocalamus asper
Shelf-life
Gamma irradiation
Microbial analysis
Organoleptic attributes

\begin{abstract}
The present investigation was performed to evaluate the potential of gamma radiation as a postharvest technology to preserve bamboo shoots. For this, Dendrocalamus asper shoots were gamma irradiated in the dose range of 0.5 to $5.0 \mathrm{kGy}$ followed by storage at $5 \pm 2{ }^{\circ} \mathrm{C}$ temperature dipped into $2 \% \mathrm{NaCl}$ solution. Acceptability of the irradiated product was assessed based on microbial, physicochemical, and organoleptic attributes as well as induced radioactivity (food safety parameter). Results of the study revealed that a dose of $2.5 \mathrm{kGy}$ was sufficient to complete removal of microbial load from the bamboo shoot up to $4 \log$ reductions when compared with the unirradiated sample. No significant changes were found in physicochemical parameters including protein, $\mathrm{pH}$, moisture, $\mathrm{HCN}$ content, and minerals. Organoleptic evaluation for different parameters were was within the acceptable criteria up to 240 days, hence $2.5 \mathrm{kGy}$ doses of irradiation had the best preservation effect on the bamboo shoots of D. asper. The result of this study suggests that irradiation could be a potential method for maintaining the quality of bamboo shoots during storage.
\end{abstract}

* Corresponding author

E-mail: ackharkwal@amity.edu (A.C. Kharkwal); akchauhan@amity.edu (Abhishek Chauhan); dushyants2000@rediffmail.com (Dushyant Singh)

Peer review under responsibility of Journal of Experimental Biology and Agricultural Sciences.

Production and Hosting by Horizon Publisher India [HPI] (http://www.horizonpublisherindia.in/).

All rights reserved.
All the articles published by Journal of Experimental Biology and Agricultural Sciences are licensed under a Creative Commons Attribution-NonCommercial 4.0 International License Based on a work at www.jebas.org.

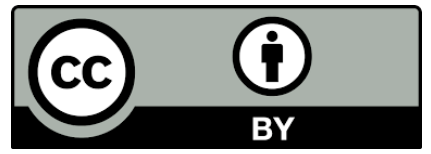




\section{Introduction}

Bambusa vulgaris, a kind plant of family Poaceae subfamily of Bambuseae, is a useful perennial woody grass (Zheng et al., 2021). It is widely distributed across the world, especially in temperate, tropical, and subtropical regions of the Asian continent with a mostly mesic to wet season (Yang et al., 2008; Nirmala et al., 2014; Leandro et al., 2020). More than 1250 species of bamboos are known worldwide that belong to 75 genera. Of these, 125 species are found in India of which only 30 are of commercial value (Changchai et al., 2020). Because of highly multipurpose properties, people from different countries address bamboos in different names Such as the Chinese called bamboos as "Friends of the people" Vietnamese as "My brother" and Indians as "Green Gold Bamboos" (Nongdam \& Tikendra, 2014). In addition to their multiple applications, juvenile bamboo shoots are acclaimed as nutrient-rich food items worldwide due to the presence of high protein, amino acids, minerals, fiber, carbohydrates content and low fat (Shinde et al., 2019). In addition, the bioavailability of nutrients and other extracts from different biomass depends on a variety of factors, such as compositions of cellulose, hemicellulose, and lignin whereas functional groups mainly depend on dietary fibers (Tao et al., 2021). The edible parts of the shoot consisted of meristematic cell tissues including regions of rapid cell division and differentiation, enclosed in protective, nonedible leaf sheaths (Changchai et al., 2020). There are few studies on the postharvest deterioration of bamboo shoots in the local market. Bamboo shoots are usually stored and sold at ambient temperature and unpackaged, which leads to bamboo shoots easily decay and remained inedible (Luo et al., 2002). It is well reported that the shelf life of bamboo shoots was limited to one to three days at ambient temperature $\left(20-25^{\circ} \mathrm{C}\right)$. Post-harvest decay is triggered due to the microbial attack of contaminated soil, inappropriate storage conditions, and environmental stresses (Chauhan \& Jindal, 2020).

To reduce post-harvest losses and extend the shelf life of fresh produce, different postharvest management techniques such as low-temperature storage, control atmosphere packaging, and surface treatment with synthetic chemicals have been widely practiced (Kaushik et al., 2010; Maraei \& Elsawy, 2017). Controlled atmosphere packaging and low-temperature storage techniques are effective and popular strategies for enhancing the shelf-life of fresh commodities however, in many reports it has been documented that these methods may not be able to control certain pathogenic fungi and bacteria such as Fusarium spp., Aspergillus spp., Bacillus spp. and other bacteria from Enterobacteriaceae family in the prevailing storage conditions (Linda et al., 2020; Hussain et al., 2021). Gamma irradiation has been successfully used as an alternative treatment for microbial disinfection and the longevity of the shelf life of fresh produce (Kaushik \& Chauhan, 2008; Prakash et al., 2000).
Further, gamma irradiation is one of the promising and effective alternative methods of processing and preserving food products (Bidawid et al., 2000). Irradiation has been recognized as an alternative to chemicals for treating fresh and dried agricultural products to overcome quarantine barriers in international trade, as a mode of decontamination, disinfestations, delaying the ripening, and senescence of fruits and vegetables for improving nutritional attributes and shelf-life (Hong et al., 2008). The study group on high dose irradiation joint "FAO/IAEA/WHO (1997)" concluded that "irradiation of any commodity up to an overall average dose of $10 \mathrm{kGy}$ presents no toxicological hazard: hence, no toxicological testing requirement of foods treated a dose level of 10 kGy or below'. Similarly, Hussain et al. (2021) reported that the irradiation up to $10 \mathrm{kGy}$ "introduces no special nutritional or microbiological problems"'. Ionizing radiation is an economically viable technology for reducing postharvest losses, extending the shelf life of perishable commodities, and maintaining the hygienic quality of fresh produce (Gonzalez-Aguilar et al., 2004). Previous studies have shown that irradiation increases the shelf life of various tropical and subtropical fruits such as papayas, mangoes, bananas, tomatoes, and kiwis (Linda et al., 2020; Hussain et al., 2021). Gamma radiation alone and in combination with refrigeration as a hurdle technology has been proven an efficient way to increase storability and extend the shelf life of numerous fruits and vegetables, such as blueberry, wild edible mushroom, and ash gourd (Tripathi et al., 2013; Sharma et al., 2020). As a technique steadily gaining worldwide acceptance, gamma radiation will become a versatile postharvest tool before long (Mahto \& Das, 2014). To the best of our knowledge, the study of bamboo shoots treated with gamma radiation has not been reported so far. Therefore, the present study was conducted to determine the effect of gamma irradiation treatment for enhancing the shelf life of bamboo shoots by analyzing the microbiological and physiochemical including nutritional parameters concerning storage periods.

\section{Materials and Methods}

\subsection{Raw material preparation}

The bamboo shoots of $D$. asper species were procured from Shillong, Meghalaya North-East region of India. The culm collection should be performed during the rainy season (June to August months). The shoot of bamboo was prepared for irradiation with gamma radiation. For this, the shoot with sheath was washed to remove any adhering dirt, dust, or any other foreign material. Later on, the sheath was removed for extraction of the tender shoot. The bamboo shoots were cut into thin slices and transferred into a broad mouth PET Jars. These Jars were properly marked and pasted by a yellow-colored chemical indicator on each PET jar to ensuring that bamboo shoot receives the exact dose, on proper gamma irradiation this yellow color converted to red. 
Table 1 Dose distribution of gamma radiations

Dose requested Dose in kGy (Min) Dose in kGy (Max)

Over dose ratio

\begin{tabular}{|cccc|}
\hline 0.5 & 0.50 & 0.57 & 1.15 \\
\hline 1.0 & 1.0 & 1.15 & 1.15 \\
\hline 2.5 & 2.74 & 3.15 & 1.15 \\
\hline 5.0 & 5.49 & 6.31 & 1.15 \\
\hline
\end{tabular}

The uncertainty of delivered doses was $\pm 10 \%$.

\subsection{Gamma Irradiation treatment}

The packaged bamboo shoot was subjected to gamma irradiation in the dose range of 0.5-5.0 kGy using Co-60 with the dose rate of $3.617 \mathrm{kGy} / \mathrm{h}$ at Shriram Applied Radiation Centre (SARC), Shriram Institute for Industrial Research, Delhi. The dose rate was determined by ceric-cerous dosimetry. To ensure the bamboo shoot receives the exact dose, the dosimeter was placed in each bamboo shoot box for each treatment at high as well as low dose spots. Irradiation was carried out at a normal temperature and atmosphere and the used dose distribution is given in table 1. After irradiation, bamboo shoots were immediately transported to the microbiology laboratory for further proceedings.

\subsection{Storage conditions}

The Pet jars of bamboo shoot dipped into brine solution were kept at $5 \pm 2{ }^{\circ} \mathrm{C}$ temperature considered as a storage condition for periodic evaluation of bamboo shoot. The samples were analyzed on day $0,15,30,60,120$ and 240 after storage. The periodic evaluation considered the microbiological, physicochemical, and organoleptic including sensory evaluation (Hussain et al., 2021)

\subsection{Microbiological analysis}

\subsubsection{Enumeration of total viable count}

Standard methods as APHA, 2015 (American Public Health Association) microbiological examination of food was used to enumerate microorganisms as $\mathrm{CFU}$ per $\mathrm{g}$ at each sampling time and treatment for 240 days of storage (Phimolsiripol \& Suppakul, 2016). The mesophilic bacteria, yeast, and mold counts were carried out using serial dilution and the pour plate method. The sample $(10 \mathrm{~g})$ was homogenized in $90 \mathrm{ml}$ of sterile $0.1 \%$ of peptone. The sample was serially diluted up to $10^{-7}$ dilutions (1:9 dilution in each tube). One $\mathrm{ml}$ of each dilution was transferred into two sterile Petri dishes ( $90 \mathrm{~mm}$ of size). About $15-20 \mathrm{ml}$ melted media plate count agar was poured into each petri dish used for the total bacterial count (Dushyant et al., 2015). The colonies were counted after $24 \mathrm{~h}$ of incubation at $37^{\circ} \mathrm{C}$. Total yeast and mold count was performed by pour plate method using potato dextrose agar. Plates were incubated at $25^{\circ} \mathrm{C}$ for 5 days. After completion of incubation, the plates were observed for the bacterial as well as yeast, and mold colonies with the help of the Quebec colony counter, and microbial counts were expressed as CFU per $g$ of bamboo shoot. Each analysis was performed in triplicate.

\subsubsection{Enumeration of coliform bacterial Population}

For enumeration of the coliform bacterial population, serial dilution and the pour plate method were used. Mix $10 \mathrm{~g}$ of homogenized sample in $90 \mathrm{ml}$ of diluents (Kaushik et al., 2009; Chauhan et al., 2010). For this, the sample was serially diluted up to $10^{-5}$ dilutions (1:9 dilution in each tube). One $\mathrm{ml}$ from each dilution was transferred into two sterile Petri dishes $(90 \mathrm{~mm}$ $\mathrm{x} 15 \mathrm{~mm}$ size). About $15-20 \mathrm{ml}$ melted media Violet Red Bile Salt Agar was used for the coliform count as per standard method and incubated at $37^{\circ} \mathrm{C}$ for $24 \mathrm{hrs}$. After completion of incubation, the plates were observed for characteristic coliform colonies with the help of Quebec Colony Counter and then calculated in terms of CFU per $g$.

\subsubsection{Screening of foodborne pathogens}

\subsubsection{Detection of Escherichia coli}

For the detection of E.coli $25 \mathrm{~g}$ homogenized sample was diluted with $225 \mathrm{ml}$ of Nutrient broth and incubated at $37^{\circ} \mathrm{C}$ for $24 \mathrm{hrs}$. Sub cultured on the MacConkey agar and Eosin Methylene blue agar plates. Plates were observed for characteristic colonies such as pink colonies on MacConkey agar and green metallic sheen colonies on Eosin Methylene blue agar plates (Chauhan et al., 2018) and further confirmation was done by Gram's staining and biochemical test (Chatterjee et al., 2020).

\subsubsection{Detection of Salmonella spp.}

For the detection of Salmonella 25g homogenized sample was diluted with $225 \mathrm{ml}$ of buffer peptone water and incubated at $37^{0} \mathrm{C}$ for $24 \mathrm{hrs} .0 .1 \mathrm{ml}$ of above enriched sample was inoculated in 10 $\mathrm{ml}$ of rappaport vassiliadis medium and then incubated at $42^{0} \mathrm{C}$ for $24 \mathrm{hrs}$, subcultured on the plates of brilliant green agar and bismuth sulphide agar. Plates were observed for characteristic colonies such as pink colonies on brilliant green agar and black metallic sheen colonies with $\mathrm{H}_{2} \mathrm{~S}$ on bismuth sulphide agar plates (Dimri et al., 2018) 


\subsection{Physicochemical characteristics of bamboo shoot}

\subsubsection{Determination of moisture content}

Moisture content was analyzed by the gravimetric method according to the method described by AOAC (2016).

\section{$2.5 .2 \mathrm{pH}$}

The $\mathrm{pH}$ of the sample was determined according to AOAC (2016).

\subsubsection{Protein content}

Protein content was determined by the Kjeldahl method as per the method described in IS: 7219

\subsubsection{HCN content}

Hydrogen cyanide content was evaluated according to titration method described by AOAC (2016)

\subsection{Organoleptic evaluation}

Sensory evaluation was conducted by an experienced sensory panel (10 members) using a nine point hedonic scale to evaluate the overall acceptability of the prepared bamboo shoots sample. Sensory attributes included color, aroma, texture, and overall acceptability towards stored bamboo shoot conditions. Sensory panelists were asked to rate their assessment on a hedonic scale from 1-9 points. Samples with 1 point, dislike extremely or not characteristic of the product and 9, like extremely or highly required characteristic of the product. Values less than 4 were considered to be unacceptable to the consumers. The sensory evaluation was done at various time intervals $0,15,30,60,120$ and 240 days for $5 \pm 2{ }^{\circ} \mathrm{C}$ storage temperature.

\subsection{Measurement of induced radioactivity}

Samples were evaluated for the parameter of induced radioactivity, if any, produced by the gamma radiation as well as to determine the residual radioactivity after decay with time before the consumption of fruits by the consumers. The radioactivity was measured by sodium iodide (thallium) 2 cubic inch size solid scintillation detector in the normal mode by gamma ray spectrometer of nucleonic private limited make. Pericarp was removed from the pulp and samples were prepared separately for pulp and pericarp. One gram sample of each was taken in the $5 \mathrm{ml}$ size counting tube and radioactivity of each sample was measured two times under identical conditions of the counter. Two blank samples were also used for the background measurement. Netradio activity was calculated by subtracting the mean background c.p.m (counts per minute) from the mean c.p.m of the sample (Table 1).

\subsection{Statistical analysis:}

All the statistical analysis were evaluated by using IBM- SPSS program 22, one-way ANOVA, and standard differences were calculated for given data. For each measurement, three replicates of samples were tested per treatment, and mean \pm standard deviation values were reported. The criteria for significance at $95 \%$ confidence are dependent on the $\mathrm{p}$-value. Differences at $\mathrm{p} \leq 0.05$ were considered to be statistically significant.

\section{Results and Discussion}

Various parameters responsible for shelf-life enhancement such as Physico-chemical, microbiological and organoleptic attributes were monitored at different storage intervals in non-irradiated control and irradiated processed samples when kept at $5 \pm 2{ }^{\circ} \mathrm{C}$ storage up to 240 days. The results of our studies are conferred here.

\subsection{Microbiological parameters}

The shelf life of D.asper shoot due to bacterial growth is a serious constraint during their storage and marketing and limits the standard shelf life of bamboo shoots to a maximum of 10 days under lower temperature conditions. The influence of radiation treatment on microbial load as total bacterial count on $D$. asper during storage at $5 \pm 2{ }^{\circ} \mathrm{C}$ was calculated. Data on microbial load revealed that irradiation treatment at $2.5 \mathrm{kGy}$ or above significantly ( $p \leq 0.05$ ) inhibited the bacterial count in bamboo shoots. In samples irradiated at $2.5 \mathrm{kGy}$ and $5.0 \mathrm{kGy}$, no microbial load was detected up to 240 days at $5 \pm 2{ }^{\circ} \mathrm{C}$ storage, thereby gamma irradiation resulting in around 4 to $6 \log$ reductions in the bacterial count after 240 days of storage. This beneficial effect of radiations at doses $2.5 \mathrm{kGy}$ and above keeping the bacterial count below detection level up to 240 days of lower temperature storage is attributed to the radio-static effect of radiations, wherein cells are destroyed upon exposure to this level of radiations for an extended period under radiation technology.

With further advancement in storage, the total bacterial counts increased irrespective of treatment; however, this count was lower in irradiated samples compared to control. After 240 days of lower temperature storage at $5 \pm 2^{\circ} \mathrm{C}$, among treatments; the dose of $2.5 \mathrm{kGy}$ was significantly ( $\mathrm{p} \leq 0.05$ ) effective in keeping the microbial load of edible bamboo shoots at very low levels and resulted in about $6 \log$ reductions in microbial load over the 240 days of storage. The results of shelf life of D.asper shoot indicate that bacterial growth was significantly $(\mathrm{p} \leq 0.05)$ faster in control and dose level of $0.5 \mathrm{kGy}$ irradiated samples. Irradiation treatment at doses of $2.5 \mathrm{kGy}$ was highly effective in extending the shelf-life of D. asper shoot compared to other irradiation doses. While the control (unirradiated) and $0.5 \mathrm{kGy}$ irradiated samples have bacterial 
growth up to 240 days of storage. Samples irradiated in the dose level of $1.0 \mathrm{kGy}$ were also unable to complete removal of microbial growth in bamboo shoot up to 240 days of lower temperature storage (Table 2). While the non-irradiated control sample showed the highest bacterial population on the same condition of storage. Thus, the effect of gamma irradiation dose of $2.5 \mathrm{kGy}$ or above in extending the microbial proliferation responsible for shelf-life has resulted in enhancing the shelf-life of $D$. asper bamboo shoot at 5 $\pm 2^{\circ} \mathrm{C}$ storage with brine solution. These results are in agreement with those obtained by Mervat et al. (2019).

Total yeast, mold count, and enumeration of coliform bacteria were found below the detection limit $(<10 \mathrm{CFU}$ per g) when analyzed by serial dilution technique at zero-day study moreover foodborne pathogens E.coli and Salmonella spp. were also not detected when tested according to Indian standard in per $25 \mathrm{~g}$ of bamboo shoot sample. As per the new food rule (FSSR, 2015) about radiation processing approved by the Government of India, fresh fruit and vegetable products belong to class 2 of the generic classification category; minimum and maximum dose for their shelf-life extension has been set at 1 and $2.5 \mathrm{kGy}$, respectively.

Gamma-irradiation is known to be an effective tool for microbial decontamination of food. It has been proven to be an effective method to reduce microbial population. In the present study, a dose dependent decrease in the bacterial population was noted. A dose of $2.5 \mathrm{kGy}$ was found to substantially reduce microbial population throughout the storage period. Similar results have been reported for irradiated lettuce (Prakash et al. 2000). Khattak et al. (2005) found that microbial colonies were eliminated on carrot and cabbage when treated with doses higher than $2 \mathrm{kGy}$. Results obtained in the present study are in agreement with that reported previously by other researchers. Thus, $2.5 \mathrm{kGy}$ was found to be the optimum dose required for maintenance of microbial safety during the storage of bamboo shoots.

\subsection{Physicochemical characteristics of bamboo shoot}

\subsubsection{Moisture content}

The moisture content is an important parameter because it is considered one of the main acceleration factors of chemical and enzymatic reactions, and it can directly influence the quality of the product (Maria et al., 2017). Results presented in table 3 suggested that the moisture content of bamboo shoots stored at $5 \pm 2^{\circ} \mathrm{C}$ temperature after gamma radiation of varying doses ( $\mathrm{kGy}$ ). The moisture content of the unirradiated bamboo shoot ranged between $90.77 \%$ and $94.73 \%$ while in the case of the irradiated bamboo shoots it was reported between $94.24 \%$ and $96.31 \%$.

There were no significant differences $(P \leq 0.05)$ in the moisture content of the unirradiated bamboo shoot on Day 0 to Day 30 . However, the percent moisture content increased significantly $(P \geq$ $0.05)$ on day 240 in the unirradiated shoots. Generally, during 0 days of storage, there were no significant differences $(P \leq 0.05)$ in the percent moisture content within radiation doses. However, from days 0 to 60 it differed significantly $(P \geq 0.05)$ in bamboo shoots treated with 1 and $2.5 \mathrm{kGy}$.

Table 2 Effect of different doses of Gamma irradiation on total bacterial count (log cfu/g sample) of bamboo shoot during storage period at

\begin{tabular}{|ccccccc|}
\hline $\begin{array}{c}\text { Irradiation dose } \\
(\mathrm{kGy})\end{array}$ & 0 & 15 & 30 & 60 & 120 & 240 \\
\hline control & $4.16 \pm 0.11$ & $4.92 \pm 0.07$ & $5.28 \pm 0.07$ & $5.95 \pm 0.13$ & $5 . .98 \pm 0.18$ & $6.17 \pm 0.07$ \\
\hline 0.5 & $2.82 \pm 0.10$ & $2.86 \pm 0.09$ & $2.90 \pm 0.08$ & $3.88 \pm 0.11$ & $3.90 \pm 0.10$ & $3.99 \pm 0.11$ \\
\hline 1.0 & $2.30 \pm 0.06$ & $2.34 \pm 0.09$ & $2.46 \pm 0.12$ & $3.53 \pm 0.08$ & $3.62 \pm 0.09$ & $3.89 \pm 0.18$ \\
\hline 2.5 & 0 & 0 & 0 & 0 & 0 & 0 \\
\hline 5.0 & 0 & 0 & 0 & 0 & 0 & 0 \\
\hline
\end{tabular}

Values are mean \pm Standard deviation $(n=3)$

Table 3 Effect of different doses of Gamma irradiation on moisture content (in $\%$ ) of bamboo shoot during storage period at $5^{0} \mathrm{C}$ in brine

\begin{tabular}{cccccccc}
\hline $\begin{array}{c}\text { Irradiation dose } \\
(\mathrm{kGy})\end{array}$ & 0 & 15 & \multicolumn{4}{c}{ Storage period(days) } \\
\hline Control & $90.77 \pm 0.04$ & $91.43 \pm 0.07$ & $91.93 \pm 0.06$ & $92.11 \pm 0.07$ & $93.74 \pm 0.08$ & $94.73 \pm 0.10$ \\
\hline 0.5 & $94.24 \pm 0.05$ & $94.67 \pm 0.05$ & $94.76 \pm 0.09$ & $94.22 \pm 0.04$ & $94.91 \pm 0.07$ & $94.30 \pm 0.08$ \\
\hline 1.0 & $94.31 \pm 0.04$ & $95.96 \pm 0.03$ & $96.06 \pm 0.09$ & $96.20 \pm 0.05$ & $94.00 \pm 0.04$ & $94.59 \pm 0.07$ \\
\hline 2.5 & $94.54 \pm 0.04$ & $96.07 \pm 0.04$ & $96.05 \pm 0.06$ & $96.31 \pm 0.09$ & $94.97 \pm 0.02$ & $94.52 \pm 0.04$ \\
\hline 5.0 & $90.59 \pm 0.08$ & $96.16 \pm 0.04$ & $96.06 \pm 0.05$ & $96.30 \pm 0.03$ & $94.56 \pm 0.08$ & $94.20 \pm 0.06$ \\
\hline
\end{tabular}

Values are mean \pm Standard deviation $(n=3)$

Journal of Experimental Biology and Agricultural Sciences http://www.jebas.org 
From table 3, it can be observed that on day 0 , the bamboo shoot irradiated at 0.5 to $2.5 \mathrm{kGy}$ resulted in a significantly $(P \leq 0.05)$ higher moisture percentage than the bamboo shoot treated with a higher dose level of $5 \mathrm{kGy}$. On day 30, bamboo shoots treated at 1 kGy to $5 \mathrm{kGy}$ showed a significantly higher moisture percentage than the other doses including the control. On day 240, irradiated bamboo shoots treated at all doses did not significantly differ from each other including unirradiated control shoots. These results are in agreement with Changchai et al. (2020) and Kleinhenz et al. (2000), those who reported that moisture content is an important factor in fresh shoots, all treatments of moisture content were found over $90 \%$ and not affected by temperature and duration of storage. Present data analysis revealed that the moisture percentage content of bamboo shoots stored at $5 \pm 2{ }^{\circ} \mathrm{C}$ was not significantly $(\mathrm{p} \leq 0.05)$ affected by the radiation treatment at various dose levels for stored up to 240 days.

\subsection{2 pH}

The $\mathrm{pH}$ plays a very important role in shelf-life studies of fruits and vegetables because all safety and quality parameters are directly dependent on the $\mathrm{pH}$ value. In the current study, the $\mathrm{pH}$ was found to be in the range of 4.61 to 4.88 for non-irradiated control samples whereas it was reported 4.20 to 4.46 for different dose level irradiated samples. The obtained results showed a slight elevation of $\mathrm{pH}$ with storage period for the control sample and modest drop in $\mathrm{pH}$ were found in irradiated samples. Most stable values in $\mathrm{pH}$ were observed at $2.5 \mathrm{kGy}$ and higher dose levels. The $\mathrm{pH}$ of the bamboo shoot was found slightly acidic across all the treatments (Table 4). The $\mathrm{pH}$ value of extracts of brine-treated shoots was lower as compared to other shoots. This might be due to the inhibition of the activity of various enzymes called polyphenol oxidase (PPO) by sodium chloride. The $\mathrm{pH}$ decreases with increase in inhibition of activity of PPO (Bajwa et al., 2016). It has been observed that the $\mathrm{pH}$ value of control and irradiated bamboo shoot didn't show any significant change during the storage period. Control and irradiated shoot samples showed almost consistent values of $\mathrm{pH}$ at different storage intervals (table 4). Irradiated samples showed similar $\mathrm{pH}$ values which did not differ significantly from the control. Almost similar results were recorded for other treatments at different storage intervals. These obtained results are in agreement with the results obtained by Majeed et al. (2014), those who indicated that gamma irradiation doses up to $1.5 \mathrm{kGy}$ may be effectively used for shelf life extension and for minimizing postharvest decay and weight loss of fruits without causing drastic changes in its $\mathrm{pH}$.

\subsubsection{Protein Content}

Bamboo shoot is a potential source for proteins for human beings with protein levels ranging from $1.49 \mathrm{~g} / 100 \mathrm{~g}$ to $4.04 \mathrm{~g} / 100 \mathrm{~g}$ and $21.1 \mathrm{~g} / 100 \mathrm{~g}$ to $25.8 \mathrm{~g} / 100 \mathrm{~g}$ on a wet and dry weight basis, respectively. The protein level in the bamboo shoot is highly dependent on the bamboo species and the maturity (Wang et al., 2020). As shown in table 5, protein content was found in the range of 4.80 to 2.80 for non-irradiated control samples whereas 4.73 to 3.20 for irradiated samples at different dose levels. The protein content of each group was not significantly impacted by

Table 4 Effect of different doses of Gamma irradiation on $\mathrm{pH}$ value of bamboo shoot during Storage period at $5^{0} \mathrm{C}$ in brine

\begin{tabular}{cccccccc}
\hline \multirow{2}{*}{$\begin{array}{c}\text { Irradiation dose } \\
(\mathrm{kGy})\end{array}$} & 0 & \multicolumn{5}{c|}{ Storage period(days) } \\
\cline { 2 - 7 } Control & $4.61 \pm 0.04$ & $4.72 \pm 0.04$ & $4.74 \pm 0.05$ & $4.76 \pm 0.04$ & $4.82 \pm 0.07$ & $4.88 \pm 0.06$ \\
\hline 0.5 & $4.46 \pm 0.02$ & $4.38 \pm 0.07$ & $4.39 \pm 0.03$ & $4.36 \pm 0.01$ & $4.33 \pm 0.09$ & $4.30 \pm 0.05$ \\
\hline 1.0 & $4.39 \pm 0.06$ & $4.30 \pm 0.03$ & $4.32 \pm 0.01$ & $4.29 \pm 0.06$ & $4.26 \pm 0.04$ & $4.24 \pm 0.04$ \\
\hline 2.5 & $4.30 \pm 0.04$ & $4.27 \pm 0.05$ & $4.25 \pm 0.06$ & $4.28 \pm 0.07$ & $4.22 \pm 0.02$ \\
\hline 5.0 & $4.31 \pm 0.04$ & $4.29 \pm 0.03$ & $4.28 \pm 0.06$ & $4.22 \pm 0.09$ & $4.24 \pm 0.03$ & $4.20 \pm 0.03$ \\
\hline
\end{tabular}

Values are mean \pm Standard deviation $(n=3)$

Table 5 Effect of different doses of Gamma irradiation on protein content (in \%) of bamboo shoot during storage period at $5^{0} \mathrm{C}$ in brine

\begin{tabular}{cccccccc}
\hline $\begin{array}{c}\text { Irradiation dose } \\
(\mathrm{kGy})\end{array}$ & 0 & 15 & \multicolumn{4}{c}{ Storage period (days) } \\
\hline Control & $4.80 \pm 0.08$ & $4.60 \pm 0.08$ & $4.00 \pm 0.08$ & $3.70 \pm 0.16$ & $3.10 \pm 0.16$ & 240 \\
\hline 0.5 & $4.70 \pm 0.10$ & $4.50 \pm 0.10$ & $4.23 \pm 0.05$ & $3.60 \pm 0.10$ & $3.30 \pm 0.10$ & $3.20 \pm 0.10$ \\
\hline 1.0 & $4.73 \pm 0.05$ & $4.60 \pm 0.10$ & $4.07 \pm 0.15$ & $3.57 \pm 0.15$ & $3.43 \pm 0.05$ & $3.00 \pm 0.10$ \\
\hline 2.5 & $4.67 \pm 0.11$ & $4.57 \pm 0.05$ & $4.40 \pm 0.10$ & $4.23 \pm 0.05$ & $3.97 \pm 0.11$ \\
\hline 5.0 & $4.63 \pm 0.05$ & $4.50 \pm 0.10$ & $4.53 \pm 0.05$ & $4.27 \pm 0.05$ & $4.20 \pm 0.10$ \\
\hline
\end{tabular}

Values are mean \pm Standard deviation $(n=3)$

Journal of Experimental Biology and Agricultural Sciences http://www.jebas.org 
irradiation. During storage of the bamboo shoots, the protein content decreased especially during the 60 to 240 days of storage. The protein content of the control group decreased faster than those of the treatment groups, which illustrated that irradiation reduced the degradation rate of proteins in bamboo shoots during storage. Further, the results of the study revealed that the protein content decreased during the storage period and reached its lowest values near the end of the storage period. Untreated bamboo shoots had the lowest protein content 2.80 followed by $0.5,1.0,2.5$, and 5.0 KGy, respectively (Table 5). The $2.5 \mathrm{kGy}$ group had found the most constant protein content during the storage period. A similar observation was reported Wang et al. (2019), these researchers were reported that soluble protein content was not significantly impacted by irradiation. During storage of bamboo shoots, they also found a faster decline in protein content value in unirradiated control samples than those of the treatment groups, which illustrated that irradiation reduced the degradation rate of soluble proteins in bamboo shoots during storage.

These results suggested that different radiation doses neither give any particular trend of increase nor decrease of the protein content of edible bamboo shoot var. D.asper. A general trend of slightly decreasing protein content was observed with increasing storage days up to 240 days at $5 \pm 2{ }^{\circ} \mathrm{C}$ whereas higher diminution was observed in unirradiated (Control) samples at the same storage conditions. A previous study by Wang et al. (2019) proved that a 3 $\mathrm{kGy}$ dose of gamma irradiation had the best effect on bamboo shoots to have preserved the macronutrients of shoots for long storage.

\subsubsection{Hydrogen Cyanide (HCN) Content}

Effect of gamma irradiation treatment on hydrogen cyanide content of bamboo shoot var. D. asper is shown in table 6. The data revealed that the $\mathrm{HCN}$ content of bamboo shoots treated with irradiation was marginally ( $\mathrm{p} \geq 0.05$ ) lower compared to control on the first day of storage. During storage decrease in $\mathrm{HCN}$ content was observed in all the treatments at various dose levels whereas the HCN content was significantly $(\mathrm{p} \leq 0.05)$ higher in control samples (Table 6). Statistical analysis of the data also indicated that for all the storage periods, the HCN content of control was different $(p \geq 0.05)$ whereas significantly $(p \leq 0.05)$ lower compared to other treatments.

The effect of gamma radiation on suppressing ethylene production has also been proven in carrot root tissues (Chervin et al., 1992). The previous report has also shown that ethylene is involved in the lignification of bamboo shoots (Luo et al., 2007). PAL is an inducible enzyme (Hughes \& Dickerson, 1989), although ethylene production of postharvest bamboo shoots is low, it may be enough to induce the activity of PAL, the present results suggested that gamma radiation may be able to delay the lignification of bamboo shoots by intensively suppressing ethylene synthesis.

\subsection{Sensory analysis}

For the sensory analysis study, the results obtained from the hedonic test for the overall acceptability of edible bamboo shoots are depicted in table 7. No significant difference $(p \leq 0.05)$ was reported between the control and bamboo shoots following irradiation on day zero. With the advancement in storage, each attribute of sensory evaluation included in the study recorded a decreasing trend in all the treatments along with control. Samples irradiated at 0.5 and $1 \mathrm{kGy}$ showed significant $(p \geq 0.05)$ changes in color as blackening at the end of the storage period. However, 2.5 and $5 \mathrm{kGy}$ appears fresh throughout the storage period up to 240 days. The texture of bamboo shoot for control and sample gave a dose less than $2.5 \mathrm{kGy}$ declined with storage.

The control and 0.5 to $1 \mathrm{kGy}$ samples showed a decrease in firmness in the later stage but Samples irradiated at $2.5 \mathrm{kGy}$ and above exhibited softening in texture, resulting in the higher score for overall acceptability. No difference in taste was found between the control and irradiated sample immediately after treatments at zero days. At the middle of the storage period of 120 days, control and sample given a dose of $0.5 \mathrm{kGy}$ were extensively spoiled due to heavy microbial load, and hence bamboo shoots could not be assessed by the sensory panel for taste at the middle and later stages of storage. The 2.5 and $5 \mathrm{kGy}$ samples showed a slight decrease in taste score up to the end of the storage period but it was lies well within the acceptance level of the hedonic scale. The data obtained were in agreement with the score on taste from the sensory panel.

Table 6 Effect of different doses of Gamma irradiation on $\mathrm{HCN}$ content (in \%) of bamboo shoot during storage period at $5^{\circ} \mathrm{C}$ in brine

\begin{tabular}{cccccccc|}
\hline $\begin{array}{c}\text { Irradiation } \\
\text { dose }(\mathrm{kGy})\end{array}$ & 0 & $\mathrm{~T}$ & \multicolumn{2}{c}{ Storage period (days) } \\
\hline Control & $36.10 \pm 0.24$ & $39.33 \pm 0.32$ & $41.50 \pm 0.29$ & $44.03 \pm 0.04$ & $49.30 \pm 0.16$ & $59.63 \pm 0.16$ \\
\hline 0.5 & $23.03 \pm 0.30$ & $25.20 \pm 0.20$ & $27.90 \pm 0.10$ & $32.60 \pm 0.17$ & $34.77 \pm 0.11$ & $37.73 \pm 0.30$ \\
\hline 1.0 & $22.80 \pm 0.10$ & $22.90 \pm 0.36$ & $22.43 \pm 0.20$ & $26.50 \pm 0.10$ & $27.07 \pm 0.30$ & $29.23 \pm 0.20$ \\
\hline 2.5 & $20.00 \pm 0.1$ & $21.13 \pm 0.05$ & $21.43 \pm 0.20$ & $23.50 \pm 0.10$ & $26.76 \pm 0.10$ & $28.00 \pm 0.17$ \\
\hline 5.0 & $18.80 \pm 0.20$ & $19.27 \pm 0.15$ & $19.87 \pm 0.05$ & $20.49 \pm 0.10$ & $25.80 \pm 0.10$ & $28.13 \pm 0.11$ \\
\hline
\end{tabular}

Values are mean \pm Standard deviation $(n=3)$

Journal of Experimental Biology and Agricultural Sciences

http://www.jebas.org 
Table 7 Effect of different doses of Gamma irradiation on organoleptic evaluation of bamboo shoot during storage period at $5^{0} \mathrm{C}$ in brine

\begin{tabular}{|c|c|c|c|c|c|}
\hline & Control & $7.6 \pm 0.4$ & $7.1 \pm 0.4$ & $7.0 \pm 0.7$ & $7.1 \pm 0.3$ \\
\hline & 0.5 & $7.5 \pm 0.3$ & $7.1 \pm 0.4$ & $7.1 \pm 0.6$ & $7.1 \pm 0.3$ \\
\hline \multirow[t]{5}{*}{0} & 1.0 & $7.5 \pm 0.3$ & $7.2 \pm 0.4$ & $7.0 \pm 0.4$ & $7.3 \pm 1.4$ \\
\hline & 2.5 & $7.7 \pm 0.4$ & $7.6 \pm 0.3$ & $7.2 \pm 0.4$ & $7.5 \pm 0.3$ \\
\hline & 5.0 & $7.5 \pm 0.4$ & $7.2 \pm 0.3$ & $7.2 \pm 0.4$ & $7.0 \pm 0.3$ \\
\hline & Control & $6.6 \pm 0.5$ & $6.9 \pm 0.3$ & $6.6 \pm 0.5$ & $6.8 \pm 0.4$ \\
\hline & 0.5 & $7.2 \pm 0.4$ & $7.0 \pm 0.2$ & $7.1 \pm 0.4$ & $6.9 \pm 0.3$ \\
\hline \multirow[t]{5}{*}{15} & 1.0 & $7.1 \pm 0.6$ & $7.2 \pm 0.7$ & $6.9 \pm 0.4$ & $7.1 \pm 0.5$ \\
\hline & 2.5 & $7.5 \pm 0.3$ & $7.4 \pm 0.4$ & $7.1 \pm 0.6$ & $7.4 \pm 0.4$ \\
\hline & 5.0 & $7.4 \pm 0.4$ & $7.0 \pm 0.3$ & $7.1 \pm 0.4$ & $7.0 \pm 0.4$ \\
\hline & Control & $5.6 \pm 0.5$ & $6.0 \pm 0.4$ & $6.2 \pm 0.4$ & $6.1 \pm 0.3$ \\
\hline & 0.5 & $6.7 \pm 0.7$ & $6.5 \pm 0.5$ & $7.0 \pm 0.4$ & $6.2 \pm 0.3$ \\
\hline \multirow[t]{5}{*}{30} & 1.0 & $7.0 \pm 0.6$ & $6.9 \pm 0.6$ & $6.9 \pm 0.4$ & $7.0 \pm 0.3$ \\
\hline & 2.5 & $7.2 \pm 0.4$ & $7.2 \pm 0.6$ & $7.1 \pm 0.5$ & $7.2 \pm 0.4$ \\
\hline & 5.0 & $7.1 \pm 0.3$ & $7.0 \pm 0.4$ & $7.0 \pm 0.3$ & $7.0 \pm 0.4$ \\
\hline & Control & $4.6 \pm 0.5$ & $4.9 \pm 0.3$ & $4.7 \pm 0.4$ & $4.6 \pm 0.4$ \\
\hline & 0.5 & $5.9 \pm 0.6$ & $5.9 \pm 0.3$ & $6.4 \pm 0.3$ & $5.0 \pm 0.4$ \\
\hline \multirow[t]{5}{*}{60} & 1.0 & $6.0 \pm 0.4$ & $6.1 \pm 0.4$ & $6.5 \pm 0.4$ & $6.6 \pm 0.4$ \\
\hline & 2.5 & $7.2 \pm 0.6$ & $7.0 \pm 0.6$ & $7.0 \pm 0.4$ & $7.1 \pm 0.4$ \\
\hline & 5.0 & $7.0 \pm 0.3$ & $6.9 \pm 0.3$ & $6.9 \pm 0.3$ & $6.9 \pm 0.3$ \\
\hline & Control & $3.8 \pm 0.4$ & $3.7 \pm 0.4$ & NA & $2.6 \pm 0.3$ \\
\hline & 0.5 & $4.8 \pm 0.4$ & $4.7 \pm 0.5$ & $3.9 \pm 0.5$ & $3.9 \pm 0.6$ \\
\hline \multirow[t]{5}{*}{120} & 1.0 & $5.7 \pm 0.5$ & $5.5 \pm 0.4$ & $5.2 \pm 0.4$ & $5.5 \pm 0.4$ \\
\hline & 2.5 & $6.9 \pm 0.3$ & $6.9 \pm 0.4$ & $6.9 \pm 0.6$ & $7.0 \pm 0.3$ \\
\hline & 5.0 & $6.8 \pm 0.4$ & $6.7 \pm 0.4$ & $6.6 \pm 0.3$ & $6.8 \pm 0.4$ \\
\hline & Control & $1.7 \pm 0.5$ & $1.5 \pm 0.7$ & NA & $1.4 \pm 0.4$ \\
\hline & 0.5 & $3.0 \pm 0.6$ & $3.1 \pm 0.4$ & NA & $2.7 \pm 0.3$ \\
\hline \multirow[t]{3}{*}{240} & 1.0 & $3.9 \pm 0.5$ & $3.6 \pm 0.4$ & $4.0 \pm 0.4$ & $3.9 \pm 0.4$ \\
\hline & 2.5 & $6.9 \pm 0.2$ & $6.6 \pm 0.5$ & $6.6 \pm 0.4$ & $6.6 \pm 0.6$ \\
\hline & 5.0 & $6.6 \pm 0.4$ & $6.5 \pm 0.4$ & $6.3 \pm 0.3$ & $6.4 \pm 0.3$ \\
\hline
\end{tabular}

Data are expressed as mean \pm standard deviation $(\mathrm{n}=10)$; NA=Not applicable

The appearance of the product plays an important role in consumer acceptance. Beyond 120 days at $5 \pm 2^{\circ} \mathrm{C}$, the control samples showed visual browning that increased with further storage. Banerjee et al. (2016) have reported similar observations in freshcut vegetables. The irradiated sample didn't show any visual browning throughout the storage period. Polyphenol oxidase (PPO), which catalyzes the oxidation of phenolic compounds to colored melanins, is the major enzyme responsible for browning in fruits and vegetables. Earlier studies demonstrated a fivefold increase in alpha resorcylic acid, an inhibitor of PPO, in irradiated
MP cut ash gourd cubes resulting in the possible prevention of browning in this product. Lowering in PPO activity as a consequence of conformational changes in the active site on exposure to radiation and a resulting browning inhibition in irradiated mushrooms has also been reported. Prathapan et al. (2019) have demonstrated that a decrease in PPO activity due to heating in fresh turmeric rhizome led to a decrease in browning. Changes in PAL activity under stress and a consequent variation in the content of various benzoic and cinnamic acid derivatives that are known to be either substrates or inhibitors of PPO have also 
been reported. The mechanism of browning inhibition in bamboo shoots by $\gamma$-irradiation in the light of the above observations needs further investigation.

The sensory quality of control samples was found to deteriorate after 60 days of storage. For radiation doses 0.5 and $1.0 \mathrm{kGy}$, the overall acceptability of the samples decreased with storage. However, at 2.5 and $5.0 \mathrm{kGy}$, it remained unchanged during storage up to 240 days at $5 \pm 2{ }^{\circ} \mathrm{C}$ temperature. Interestingly, the acceptability of samples at $2.5 \mathrm{kGy}$ was higher than that of $5.0 \mathrm{kGy}$ at all stages of storage. These samples at the dose level 2.5 and 5.0 kGy scored better in all three attributes i.e., color, texture, and taste making them more acceptable as compared to the other samples on the storage period for 240 days. The hedonic analysis thus indicated that radiation processed samples at a dose of $2.5 \mathrm{kGy}$ had the highest scores throughout the storage period.

\subsection{Measurement of induced radioactivity}

Measurement of induced radioactivity (food safety parameter) from the data collected from all the samples it was found that no net induced radioactivity was observed in the stored samples of bamboo shoots. The possible reason for this may be that no nuclear reaction may take place as the metal ion concentration in the bamboo shoot is very low. Thus, from the consumption point of view, no harmful residual radiation in the cut pieces bamboo shoot was reported.

\section{Conclusion}

Results of the current study revealed that a minimum dose of 2.5 $\mathrm{kGy}$ is adequate for the preservation of bamboo shoots of $D$. asper because it did not have any adverse effect on the treated shoots. Hence gamma irradiation technique was found to be a very important research tool for extending the shelf-life of post harvested bamboo shoot $D$. asper nutritionally, and presently the shoots are consumed mostly as fresh or fermented forms. There is much loss of shoots due to microbial deterioration during storage and transportation and currently, no proper processing and storage methods were available for the preserving of these shoots. Being a non-climacteric fruit, it perishes soon after harvest. Gammairradiation treatment of bamboo shoot proved significantly ( $\mathrm{p} \leq$ 0.05 ) beneficial in maintaining its storage quality including nutritional as well organoleptic attributes and decreasing the microbial load. Among the selected radiation doses, $2.5 \mathrm{kGy}$ of gamma irradiation dose significantly effective to store the bamboo shoots at $5 \pm 2{ }^{\circ} \mathrm{C}$ temperature up to 240 days. No induced radioactivity was produced in the irradiated fruits Therefore, it is suggested that gamma radiation can be a potential non-chemical method for preserving postharvest bamboo shoots. The extension in shelf -life through gamma irradiation will help in overcoming the constraints involved in the handling and storage of the bamboo shoots for its use in the food industry.

\section{Acknowledgements}

The authors are thankful to Shriram Institute for Industrial Research, Delhi; for facilitating and encouraging the research work.

\section{Conflict of Interest}

The authors declare that there is no conflict of interest regarding the publication of this article.

\section{References}

AOAC (2016) Official methods of analysis. $20^{\text {th }}$ edition. Washington DC.USA Association of Official Analytical Chemists.

APHA (2015) $5^{\text {th }}$ edition Compendium of methods for the Microbiological examination of foods.

Bajwa HK, Nirmala C, Koul A, Bist MS (2016) Changes in organoleptic, physicochemical and nutritional qualities of bamboo shoots of an edible bamboo Dendrocalamus hamiltonii nees and arn. Ex munro during processing and Journal of Food Processing and Preservation. DOI: 10 1111/jfpp. 12716

Banerjee A, Chatterjee S, Variyar PS, Sharma A (2016) Shelf-life extension of minimally processed ready-to-cook (RTC) cabbage by gamma irradiation. Journal of Food Science and Technology 53(1): 233-244

Bidawid S, Farber JM, Sattar SA (2000) Inactivation of hepatitis A virus (HAV) in fruits and vegetables by gamma-irradiation. International Journal of Food Microbiology 57: 91-97.

Changchai S, Sumrit T, Kitpot, T, Inrirai P (2020) Impact of storage condition on postharvest preservation of fresh Bambusa sp. Shoot. Food Research 4(1):57-63.

Chatterjee R, Singh D, Aggarwal ML, Varma A, Chauhan A, Tripathi S (2020) Assessment of Murraya koenigii Leaf Extract against New Multiple Drug Resistance Human Enteric Pathogens. Asian Journal of Chemistry 32 (10): 2647-2652.

Chauhan A, Chauhan G, Gupta, PC, Goyal P, Kaushik P (2010) In vitro antibacterial evaluation of Anabaena sp. against several clinically significant microflora and HPTLC analysis of its active crude extracts. Indian Journal of Pharmacology 42(2):105.

Chauhan A, Garg S, Ranjan A (2018) Prevalence of microbial contamination of mobile cell phones in general population of Delhi, India. Journal of Experimental and Clinical Microbiology $1(1): 12-15$. 
Chauhan A, Jindal T (2020) Microbiological Methods for Environment, Food and Pharmaceutical Analysis. Springer Nature.DOI: 10.1007/978-3-030-52024-3

Chervin C, Triantaphylides C, Libert MF, Siadous R, Boisseau P (1992) Reduction of wound-induced respiration and ethylene production in carrot root tissues by gamma irradiation. Postharvest Biology and Technology 2 (1): 7-17.

Dimri AG, Prasad R, Chauhan A, Aggarwal ML, Varma A (2018) Characterization of soil actinomycete isolate against gram-positive and gram-negative food borne bacteria. Indian Journal of Environmental Protection 38(1):1004-1015.

Dushyant S, Dimri AG, Chatterjee R, Pandita A, Aggarwal ML (2015) Microbiological profiling vendor and commercially packed mixed fruit juices: A case study suburb of Delhi NCR, India. World Journal of Pharmacy and Pharmaceutical Sciences 10(4): 1150-1163

FAO/IAEA/WHO (1997) Joint FAO/IAEA/WHO study group on high dose irradiation, wholesomeness of food irradiated with doses above 10 kGy, (1997) Geneva, Switzerland, WHO Technical report series: 890 .

Food Safety and Standards Authority of India (2015) Draft Food Safety and Standards (Packaging and Labelling) \&(Food product standards and food additives) (amendment) Regulations (2015) related to inclusion of New Atomic Energy (Radiation Processing of Food and Allied Products)., Rules, 2012. Food Safety and Standard Authority of India, New Delhi, India.

Gonzalez-Aguilar G, Wang CY, Buta GJ (2004) UV-C irradiation reduces breakdown and chilling injury of peaches during cold storage. Journal of the Science of Food and Agriculture 84(2): 415422.

Hong YH, Park JY, Park JH, Chung MS, Kwon KS, Chung K (2008) Inactivation of Enterobacter sakazakii, Bacillus cereus and Salmonella typhimurium in powdered weaning food by electron beam irradiation. Radiation Physics and Chemistry 77(9) 10971100 .

Hughes RK, Dickerson AG (1989) The effect of ethylene on phenylalanine ammonia lyase (PAL) induction by a fungal elicitor in Phaseolus vulgaris. Physiological and Molecular Plant Pathology 34(4): 361-378

Hussain PR, Rather SA, Suradkar PP, Omeera A (2021) Gamma Irradiation treatment of minimally processed kiwi fruit to maintain physicochemical quality and prevent microbial proliferation during refrigerated storage. Journal of Food Processing and Preservation 45 (4): 15309.
Kaushik P, Abhishek C, Pankaj G (2009) Screening of Lyngbya majuscula for potential antibacterial activity and HPTLC analysis of active methanolic extract. Journal of Pure and Applied Microbiology 3(1): 169-174.

Kaushik P, Chauhan A (2008) Antibacterial Potential of aqueous and organic extracts of $\mathrm{N}$. Commune: A Cyanobacterium. VEGETOS 21(1): 77-80.

Kaushik P, Goyal P, Chauhan A, Chauhan G (2010) In vitro evaluation of antibacterial potential of dry fruit extracts of Elettaria cardamomum Maton (ChhotiElaichi). Iranian Journal of Pharmaceutical Research 9(3): 287.

Khattak AB, Bibi N, Chaudry MA, Khan M, Khan M, Qureshi MJ (2005) Shelf-life extension of minimally processed cabbage and cucumber through gamma irradiation. Journal of Food Protection 68(2): $105-110$

Kleinhenz V, Gosbee M, Elsmore S, Lyall TW, Blackburn K, Harrower K, Midmore DJ (2020) Storage methods for extending shelf life of fresh, edible bamboo shoots [Bambusa oldhamii (Munro)]. Postharvest Biology and Technology 19 (3): 253-264.

Leandro TD, Scatena VL, Clark LG (2020) Comparative leaf blade anatomy and micromorphology in the systematics and phylogeny of Bambusoideae (Poaceae: Poales). Botanical Journal of the Linnean Society 192(1):165-83.

Linda JH, Feng Y, Vanessa ML, Jung J (2020) Growth and survival of foodborne pathogens during soaking and drying of almond (Prunus dulcis) kernels.Journal of food protection 83(12):2122-2133.

Luo Z, Xu X, Cai Z, Yan B (2007) Effects of ethylene and 1methylcyclopropene (1- MCP) on lignification of postharvest bamboo shoots. Food Chemistry 105 (2): 521-527.

Luo ZS, Xi YF, Fu GZ, Lu CX (2002) Effect of heat treatment on cell wall components in relation to cell wall hydrolase of excised bamboo shoots. Acta Horticulturae Sinica 29 (1):43-46.

Mahto R, Das M (2014) Effect of gamma irradiation on the physico-mechanical and chemical properties of potato (Solanum tuberosum L.). 'KufriSindhuri', in nonrefrigerated storage conditions. Postharvest Biology and Technology 92: 37-45.

Majeed A, Muhammad Z, Majid A, Shah AH, Hussain M (2014) Impact of low doses of gamma irradiation on shelf life and chemical quality of strawberry (Fragaria xananassa) cv. Corona. Journal of Animal and Plant Sciences, 24(5):1531-1536. 
Maraei R, Elsawy KM (2017) Chemical quality and nutrient composition of strawberry fruits treated by gamma irradiation. Journal of Radiation Research and Applied Sciences 10(1): 80-87.

Maria HF, Bcralde AL, Maria T (2017) Young bamboo culm flour of Dendrocalamus asper: Technology properties for food application. Food Science and Technology 76 (2): 230-235.

Mervat MA, Asael MA, Nasr EH (2019) Extension shelf life of batte by using hydrocolloids and gamma irradiation. Journal of Radiation Research and Applied Sciences, 8(4):570-577.

Nongdam P, Tikendra, L (2014) The nutritional fact of Bamboo Shoots and their usage as important traditional foods of Northeast India. International scholarly research noticesID 679073. DOI: $10.1155 / 2014 / 679073$.

Nirmala C, Bisht MS, Laishram M (2014) Bioactive Compounds in Bamboo Shoots: Health Benefits and Prospects forDeveloping Functional Foods. International Journal of Food Science and Technology 49(6): 1425-1431. DOI: 10.1111/ijfs.2014.49.

Phimolsiripol Y, Suppakul P (2016) Technique in Shelf-life evaluation of food products. Module in Food Sciences 5(3): 1-8

Prakash A, Inthajak P, Huibregtse H, Caporaso F, Foley DM (2000) Effect of low dose gamma irradiation and conventional treatments on shelf life and quality characteristics of diced celery. Journal of Food Science 65 (6): 1070-1075.

Prathapan A, Lukhman M, Arumughan C, Sundaresan A, Raghu KG (2019) Effect of heat treatment on curcuminoid, colour value and total polyphenols of fresh turmeric rhizome. International Journal Food Science and Technology 44:1438-1444.
Sharma P, Sharma SR, Mittal TC (2020) Effect and application of Ionizing Radiation on Fruits and vegetables: A review. Journal of Agriculture Engineering 57(2):97-126.

Shinde ST, Sawate AR, Kshirsagar RB, Patangar SS (2019) Effect of Pre-treatment on quality attributes of fresh bamboo shoot pickle. The Pharma Innovation Journal 8(3):257-260.

Tao Y, Wang T,Huang C, Lai C, Ling Z, Yong Q (2021) Effect of seleno-Sesbania canabina galactomannan on anti-oxidative and immune function of macrophage. Carohydrate polymers261:117833.doi10.1016/j.ijbiomac.2020.01.281.

Tripathi J, Chatterjee S, Vaishnava J, Variyar PS, Sharma A (2013) Gamma irradiation increases storability and shelf life of minimally processed ready-to cook (RTC) ash gourd (Benincasa hispida) cubes. Postharvest Biology and Technology 76(13): 17-25.

Wang J, Jiang J, Wang J, Wang Z, Yang X, Jia L (2019) The influence of gamma irradiation on the storage quality of bamboo shoots. Radiation Physics and Chemistry 159: 124-130.

Wang Y, Jiang J, Chen J, Wang D, Ye F, He Y, Hu Z, Zhao G (2020) A systematic review, storage, processing of bamboo shoots: Focusing the nutritional and functional benefits. Journal of Functional Foods 159: 124-130

Yang Q, Duan ZB, Wang ZL, Kai-Hong HE, Sun QX, Peng ZH (2008) Bamboo Resources, Utilization and Ex-situ Conservation in Xishuangbanna, South-eastern China. Journal of Forestry Research 19(6):79-83. DOI: 10.1007/s11676-008-0015-6.

Zheng Y, Yu Y, Lin W, Jin Y, Yong Q, Huang C (2021) Enhancing the enzymatic digestibility of bamboo residues by biphasic phenoxyethanol-acid pretreatment. Bioresource Technology 325:124691. DOI: 10.1016/j.biortech.2021.124691. 